\title{
Histological Study of the Effect of Ethanolic Leaf Extract of Sida Acuta on the Cerebral Cortex of Adult Wistar Rats
}

\author{
M .A Eluwa, P. S Ofem, O. R Asuquo*, A. O. Akpantah, T. B. Ekanem, \\ Department of Human Anatomy, Faculty of Basic Medical Sciences, College of Medical Sciences, University of \\ Calabar, PMB 1115, Calabar, Nigeria
}

\begin{abstract}
The pantropical shrub, Sida acuta is a medicinal plant used in the treatment of a variety of ailments. This study was to investigate the effect of ethanolic leaf extract of Sida acuta on the histological feature of the cerebral cortex. Twenty female rats weighing between 150-200g were used for this study. The rats were divided into four groups labeled $A, B, C$, and $D$ with each group consisting of five rats. Group $A$ served as the control and received distilled water, while groups $B, C$ and $D$, the experimental groups, received $200 \mathrm{mg} / \mathrm{kg}, 400 \mathrm{mg} / \mathrm{kg}$ and $600 \mathrm{mg} / \mathrm{kg}$ of ethanolic leaf extract of Sida acuta respectively for 14 days. The extract was orally administered with the aid of an orogastric tube. Twenty four hours after the last administration, the animals were sacrificed by chloroform inhalation method; the cerebral cortex dissected out and fixed in 10\% formal saline for routine histology and thereafter stained using Haematoxylin and Eosin method. Histological observations of the cerebral cortex showed 4 basic zones namely marginal, cortical, intermediate and subventricular, while animals administered with $200 \mathrm{mg} / \mathrm{kg}$, and $600 \mathrm{mg} / \mathrm{kg}$, showed hyperplasia of cells in the cortical, intermediate and sub-ventricular layers, respectively. Animals that received $400 \mathrm{mg} / \mathrm{kg}$ of the extract showed hypertrophy of cell in the intermediate and sub-ventricular layers. This result suggests that high doses of ethanolic leaf extract of Sida acuta may cause some neurological disorders; therefore caution must be taken when used for the treatment of various ailments.
\end{abstract}

Key word: Cerebral cortex, Hyperplasia, Hypertrophy, Neurological, Sida acuta, Subventricular.

\section{Introduction}

Traditional medical knowledge based on the use of natural products from plants has often been the basis for discovering new drugs. It is estimated that $80 \%$ of many developing countries population still use plant-based traditional medicines (1). These natural products and their derivatives represent almost half of the drugs approved since 1994 (2). Sida acuta is a tropical weed of pastures, road sides and waste areas. Research carried out by Sofowara (3) revealed that juice from leaf of Sida acuta is antihermetic for intestinal worms, the root inhibit embryo implantation or growth in the mice (4). Some herbalists have claimed the traditional use of this plant to cure infections such as malaria, ulcer, fever, gonorrhea, abortion, breast cancer following inflammation, wound infections. Some of these claims have also been experimentally proven (5-6). The leaf is most frequently used against various infections. Phytochemical evaluation of Sida acuta leaf revealed the presence of alkaloids, saponins, flavonoids, anthraquinones, cardenolides, polyphenols and tannins (7). The plant contains chemical constituents such as cryptolephine 5-methylindolo (2-3b)-quindoline, ecdysterone, ephedrine, hentriacontane and hypolaetin-8-glucoside (8-9). Kuniata and Rapp (10) have also reported that leaf of Sida acuta is not liked by cattle due to the presence of different chemicals including alkaloids.

Sida acuta is mainly known for its healing effects and used as healing agents, and is being used as an herbal medicine for the treatment of malaria, ulcer, gonnorhoea, wound infection, asthma, headache, cold, fever, cough, skin disease and facial paralysis (11). Sida acuta has also been reported to have contraceptive property (12), hepatoprotective (13), antibacterial (14) and antimicrobial activity (15). The cerebral cortex plays a key role in memory, attention, perceptual awareness, thought, language and consciousness (16). Due to the importance of the cerebral cortex, this research was carried out to investigate likely effect of the ethanolic extract of Sida acuta leaf on the cerebral cortex of adult wistar rats.

\section{Material and methods}

Twenty (20) female rats were used for this study. They were obtained from the Department of Pharmacology, University of Calabar, Cross River State, Nigeria and weighed between 120g-150g. The rats were housed in well ventilated cages and kept in the animal house in the Department of Human Anatomy, University of Calabar. Permission was sort for the study from the departmental Ethical Committee and the study was carried out according to the principles prescribed for laboratory animal use. They were fed with normal rat chow and water was provided ad libitum throughout the duration of the experiment. 


\subsection{Preparation of the extract}

Fresh leaves of Sida acuta weed were obtained locally from the Calabar botanical garden, Mary Slessor Road, Calabar, Cross River state, Nigeria. They were then washed under the running tap water to remove the impurities after which they were left to dry at normal room temperature for seven days. The dried leaves were then grinded to powder using electric blender. The extraction method involved cold ethanolic extraction, where a known weight of the blended sample was soaked in ethanol for 24hours and then the extract was filtered and evaporated to dryness at room temperature to obtain the crude extract.

\subsection{Experimental protocol}

The rats in Group A serve as the control group and received distilled water while the rats in Groups B,C and D the experimental animals received $200 \mathrm{mg} / \mathrm{kg}, 400 \mathrm{mg} / \mathrm{kg}, 600 \mathrm{mg} / \mathrm{kg}$ body weight of ethanolic leaf extract of Sida acuta respectively for 14 days using orogastric tube. Twenty four hours after the last administration, the rats were sacrificed using the chloroform inhalation method. The cerebral cortex was extracted and immediately fixed in formal-saline for histological studies.

\section{Results}

Histological study of the cerebral cortex using H\&E staining method in the control group A, showed four basic histological layers. These zones from outward - inwards are Marginal (M), cortical (C), Intermediate (I) and sub-ventricular (SV) (Fig1). Hypoplasia of cells in the cortical, Intermediate and sub-ventricular zones was intense in group that received $200 \mathrm{mg} / \mathrm{kg}$ of leaf extract (Fig 2).

Hypertrophy of cells was seen in the groups that received $400 \mathrm{mg} / \mathrm{kg}$ and $600 \mathrm{mg} / \mathrm{kg}$ of the leaf extract especially in the sub-ventricular and ventricular zones when compared with the control and treated groups that received $200 \mathrm{mg} / \mathrm{kg}$ and $600 \mathrm{mg} / \mathrm{kg}$ of the leaf extract (Fig 3, Fig 4).

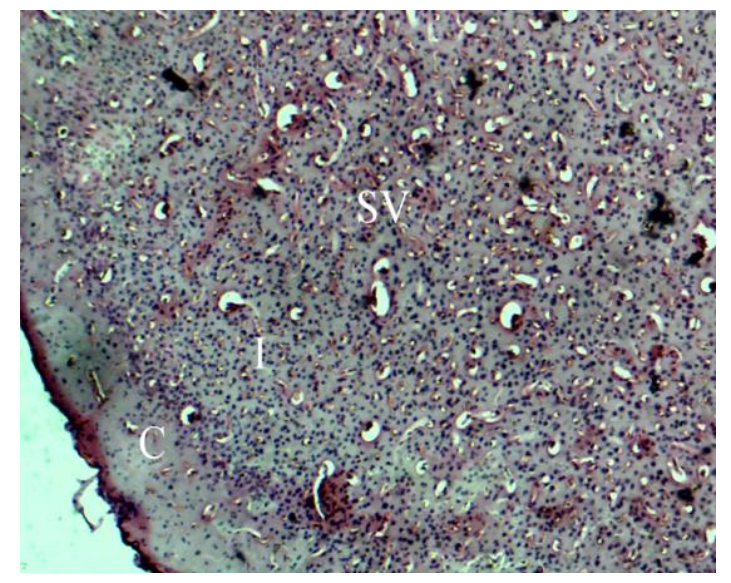

Fig 1: Cerebral cortex of control animals showing 4 basic zones, Marginal (M), cortical (C), Intermediate (I) and sub-ventricular (SV)

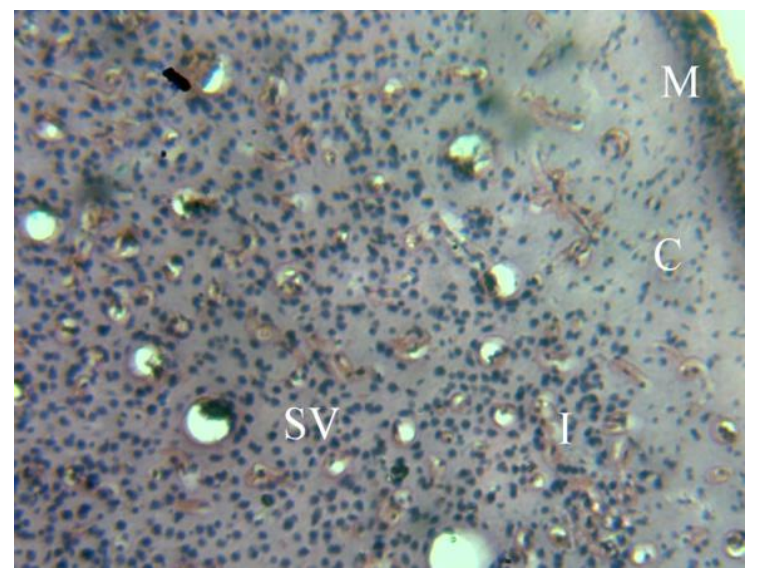

Fig 2: Cerebral cortex of $200 \mathrm{mg} / \mathrm{kg}$ showing slight hypoplasia of cells in the cortical, Intermediate and subventricular layers (H \& E X 400) (H \& E X 400) 


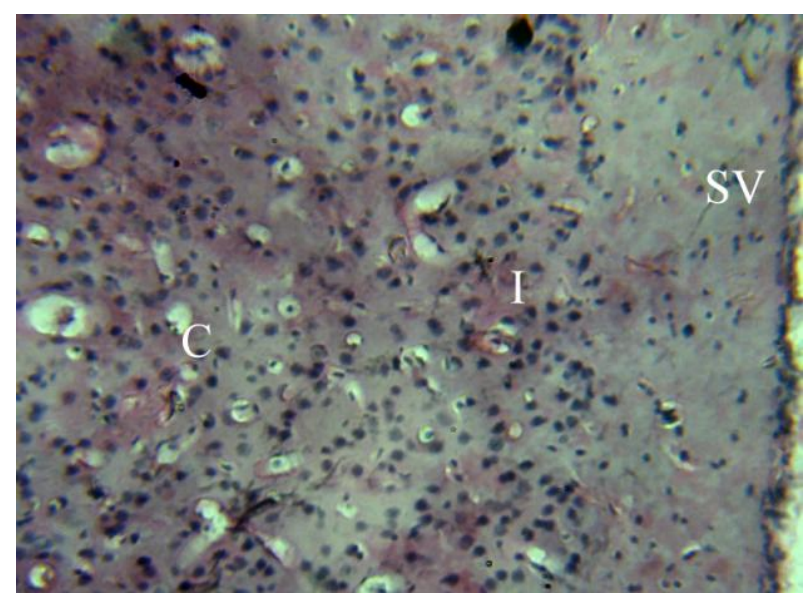

Fig 3: Cerebral cortex of $400 \mathrm{mg} / \mathrm{kg}$ showing hypertrophy of cells

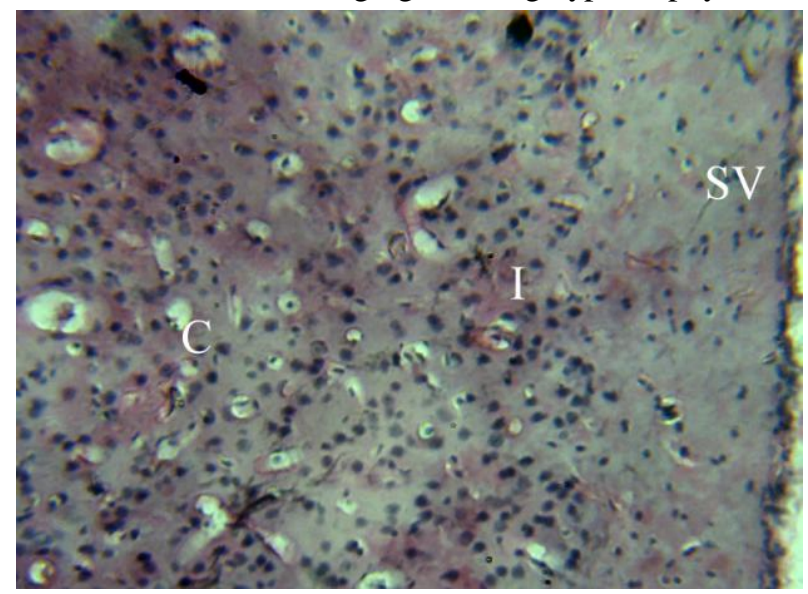

Fig 4: Cerebral cortex of $600 \mathrm{mg} / \mathrm{kg}$ showing intense hypoplasia and in the cortical, Intermediate and subventricular layers (H \& E X 400)slight hypertrophy of cells in the cortical, Intermediate and sub-ventricular layer (H \& E X 400).

\section{Discussion}

Medicinal plants have been used as healing agents in many parts of the world especially Africa, where access to formal health care is limited. The use of herbs provides an indication of beliefs about illnesses and their treatment and may conflict with beliefs of workers in the formal health system (17). The cerebral cortex is a sheet of neural tissue that is outer-most to the cerebrum of the mammalian brain. It plays a key role in memory, attention, perceptual awareness, thought, language and consciousness (18). In this study, the control group A of the cerebral cortex showed 4 basic histological layers, the $200 \mathrm{mg} / \mathrm{kg}$ dosage showed slight hypoplasia of cells in the cortical, intermediate and sub-ventricular layers, the $400 \mathrm{mg} / \mathrm{kg}$ dosage showed hypertrophy of cells in the cortical, intermediate and sub-ventricular layer and the $600 \mathrm{mg} / \mathrm{kg}$ dosage showed intense, hypoplasia of cells in the cortical, intermediate and sub-ventricular layers when compared with the control group and the group that received $200 \mathrm{mg} / \mathrm{kg}$ of the extract.

These changes may be due to the effect of some alkaloids in the ethanol leaf of Sida acuta; and the GCMS analysis of this alkaloids extracts of Sida acuta led to the isolation of 2 major constituents such as cryptolepine and quindoline (8). These indolizidine alkaloid has been identified as the toxic constituent of Sida species responsible for the neurological disorders mainly in animals (19). Although the two major alkaloids in the extract-cryptolepine and quindoline, exhibit good antimicrobial activity against several test microorganisms (8). However, Sida acuta only showed significant protection of 55\% at the highest dose out of a $100 \%$ and as such it is unsafe to take this extract orally because it contains ephedrine which can cause serious side effects including hypertension, myocardial infarction, seizure, stroke and psychosis; cells of the cerebral cortex are related to the integration of sensory information and initiation of voluntary motor responses (20).

In conclusion, Sida acuta ethanolic leaf extract may affect the functions of the cerebral cortex indicated by hypoplasia and hypertrophy of cells in the cortical, intermediate and sub-ventricular layers. 


\section{References}

[1]. Bodeker G., Willcox ML. New Research Initiative on plant-based antimalarials. Lancet, 2000, 335; 761.

[2]. Harvey A.L.. Natural Products in Drug Discovery Today.. Strathclyde Institute of pharmacy and Biomedical Sciences, University of Strathclyde . 2008, 13 (19-20), 894-901

[3]. Sofowara E.A.. Medicinal Plant and Traditional Medicine in Africa. John Wiley and Sons. Ltd. New York 1992; pp. 96-105.

[4]. Itah A.Y., Opara A.A. Prevalence Characterization and Antibiogram of Bacillus Ceveus Stains Isolated from Canned Food sold in Calabar. Nig. J.med. Lab. Sce.4, 1990; 87-90.

[5]. Kayode J. Conservation of Indigenous Medicinal Botanicals in Ekiti state, Nigeria. J. Zheijiang University Sci. B. 2006, 7: 713718 .

[6]. Edeoga H.O., Okwu D.E. and Mbaebrie B.O. Phytochemical constituents of some Nigeria medicinal plants. Afri.J.Biotechnol; 2005, 4: 685-688

[7]. Benzouzi,J. T.,Prado R.,Menan,H.,Valentin A.,and Roumestan, C; Mallie, M.,Pelissier. Y.,Blache Y. Studies of medicinal plants of Ivory Coast:Investigation of Sida acuta for invitro antiplasmodial activities and identification of an active constituent.Phytomedicine, 2004, 1: 338-341.

[8]. Karou D., Savadogo A, Canini A, Yameogo S, Montesano C, Simpore J et al. Antibacterial activity of alkaloids from Sida acuta. African J. Biotechnol,2006, . 5,: 195-200.

[9]. Malairajan P., Gopalakrishnan G., Marasimhan S. \& Veni K. J. K. Analgesic activity of some Indian Medicinal Plants. J. Ethnopharmacol. 2006, 106: 425-428.

[10]. Kuniata L. \& Rapp G. (2001). Bio control of Sida rhombifolia in Papua New Guinea 2001 .http://www.nt.Gov.au/dpf/pubcat/agnotes/542.htm.4p.

[11]. Akilandeswari S, Senthamarai R, Valarmathi R \& Prema S. Wound healing activity of Sida acuta in rats. Int J PharmTech Res ,2010, 1(4): 1260-1266.

[12]. Londonkar R.C., Patil S. J \& Patil S.B.. Phytochemical and contraceptive property of Sida acuta Burm FI. IIN in albino rats. Int J PharmaTech Res, 2009, 1(4): 1260-1266.

[13]. Sreedevi CD, Latha PG, Anay P, Suja SR, Shyamal S, Shine VJ et al. hepatoprotective studies on Sida acuta Burm. F. J Ethnopharmacol. 124 (2), 2009. 171-179.

[14]. Iroha IR, Amadi ES, Nwuzo AC \& Afiukwa FN. Evaluation of the antibacterial activity of extracts of Sida acuta against clinical isolates of Staphyloccus aurens isolated from Vhuman Immunodeficiency Virus/ Acquired Immunodeficiency Syndrome patients. Res J Pharmacol, 2009, 3(2): 22-25.

[15]. Akinlandeswari S, Senthsmsrai R, Prema S \& Valamathi R. Antimicrobial activity of leaf extyracts of Sida acuta Burm. Int J Pharma Sc Res, 2010, 1(5): 248-250.

[16]. Kandel, Eric R., Schwartz, James H., Jessell \& Thomas M. Principles of Neural science Fourth Edition. United State of America. Mc Graw-hill. 2000; p.324.

[17]. Morgan M., Watkins C.J. Managing hypertension: Beliefs and Responses to medication among Cultural groups. Social Health Illn, 1998,10;561-578.

[18]. Notor SC, Flint AC, Weissman TA, Dammernam RS \& Kreigstein AR. "Neuron derived from radial glial cells establish radial units in neocortex". Nature, 2001, 409(6821); 714-720.

[19]. Driemeier D. Colodel, E.M., Gimeno E. J \& Barros SS. "Lysosomal storage Disease cause by Sida carpinifolia poisoning in Goats". Veterinary pathology, 2000, 37(2);153-159.

[20]. Ghez C, Vicario D, Martin JH \& Yumiya H. role of the motor cortex in the initiation of voluntary motor responses in the cat. Electroencephalogr Clin Neurophysio Suppl, 1982, 409-414. 